\title{
地下空洞周辺の伝熱に関する研究 \\ A STUDY ON HEAT CONDUCTION AROUND CAVERNS
}

佐藤邦明*・伊藤 洋**

By Kuniaki SATO and Yo ITO

\begin{abstract}
The caverns are of use for such various purposes as the electric power station, fuel stock piling and repository of exhausting materials. The present study deals with the heat conduction around the oil cavern and the canister for reposing the radioactive nuclides. The measurement of temperature is done by thermometer as well as the photographic observation due to Thermosensitive liquid-crystal-film in a laboratory. The experimental results are compared with several numerical calculations obtained from the modified Fluid in Cell method on the basis of a set of energy and groundwater equations.
\end{abstract}

\section{1. まえがき}

昨今, 燃料地下備蓄や核廃棄物の岩盤地下処分にかか わる伝熱現象がとりわけて注目されている.たとえば, 燃料備蓄に関しては加温式原油貯蔵や液化ガスの常圧低 温貯蔵に伴って, 岩盤空洞の周辺地山に伝熱する ${ }^{1), 21}$. また，高レベル核廃棄物の岩盤処分に当たっては空洞下 部のキャニスター周辺で放射性核種の残留崩壊による発 熱によって $300^{\circ} \mathrm{C}$ 程度の高温伝熱帯が現われるといわ れ，地下水への核種拡散問題とともに研究されてい $3^{3), 4)}$. 周知のように空洞熱源周辺の伝熱帯の発生によっ て, 岩盤の力学的性質が影響を受け, 変質・劣化したり, 物質拡散現象が助長されることもあり得るため, この伝 熱帯の範囲・広がりや温度分布, また同時に地下水流に よる熱輸送の影響などを明らかにしておく必要がある. この種の岩盤伝熱については今日までに本邦はもとより 諸外国でも系統的にあまり取り扱われていないが，岩石 の伝熱にかかわる基礎物性についてはすでにかなり研究 が集積されている(5) 7).こういった背景にあって, 本論

* 正会員 工博 埼玉大学助教授 工学部 ( 于338 浦和市下大久保 255)

** 正会員 (株)熊谷組 原子力開発室土木技術部 (埼玉大学 研究生)（开162 新宿区津久戸町 17-1)
では然料地下備蓄と核廃棄物の岩盤処分にかかわる $2 つ$ の伝熱問題に着目して，伝熱の形態，分布・広がりとそ の経時変化を究明することを目的に，いくつかの室内実 験を行い, 新しく開発した変形 FLIC 法によって伝熱 解析を試み，検討を加えた。いくつかの新しい知見を得 たのでそれらをここにまとめたものである.

\section{2. 解析モデルと変形 FLIC 法}

\section{（1） 解析モデルと条件}

加温式原油空洞と核廃棄物処分空洞の 2 つを対象にし て伝熱解析するに当たり岩盤二次元モデルを Fig. 1 およ び Fig. 2 のように設定することにする．Fig. 1 には完全 不透水基盤上に透水性岩盤地山があり, 岩盤地山の上部 に沖積層が带水しているとし, 岩盤地山に加温式貯油空 洞（貯油率 $95 \%$ を想定）を設ける．ここでいう加温式 原油空洞は, $50 \sim 60^{\circ} \mathrm{C}$ に加熱して原油の固化およびス ラッジの沈積を防止しつつ貯蔵する方式を指すが，この 場合, 加温貯油による伝熱は地下空洞への涌水を伴いつ つ起こるので, 伝熱分布とその経時変化および伝熱量が 地下水流の影響を受けることとなる，一方，他の伝熱モ デルとして, Fig. 2 のうに沖積層をもつ透水性岩盤内 に高レベル核廃充物格納キャニスター (canister) をも つ空洞を設けた場合を考えることにする．今日いわれて 


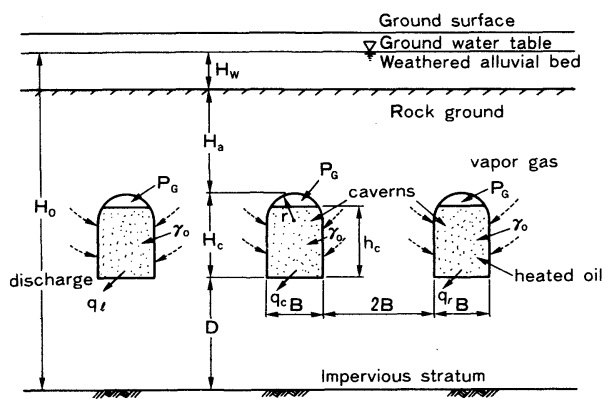

Fig. 1 Cavern model with heated fuel.

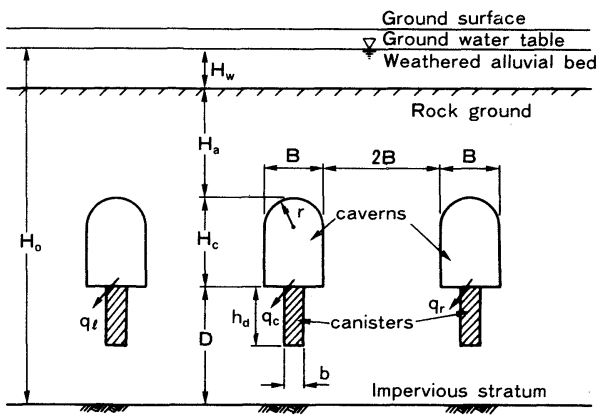

Fig. 2 Cavern model with repository canister for reposing radioactive nuclides.

いるキャニスターは原子力発電所より出る使用済放射性 核種を一定量長期に格納しておくための容器の役割をも つもので, 高レベルの放射性核種をある濃度で保存して おくと, 格納された核種自然崩壊による放熱が起こると されている4). この場合, 実用上はキャニスタ一周辺を 工学バリア (engineering barrier) で保護・強化するこ ととなるので, 本論では計算手法の提案と同時にキャニ スタ一周辺の伝熱解析を行って空洞への湧水による地下 水運動の伝熱への影響も併せて基礎的に調べることを目 的とする.

伝熱解析は, 定常の地下水流れの基礎式と伝熱方程式 を連立させて解析を進める方法をとる. 基礎式はおのお の,

$\operatorname{div}(k \cdot \operatorname{grad} h)=0:$ 定常地下水流の式

$(\rho c) \frac{\partial T}{\partial t}+\operatorname{div}\left[(\rho c)_{f} V T\right]=\operatorname{div}(x \cdot \operatorname{grad} T)$

: 伝熱の式 ${ }^{8)}$

である.ここに, $k$ : 透水係数, $h$ : ピエゾ水頭, $(\rho c)$ : 飽和多孔媒体の等価熱容量, $T$ : 温度, $t$ : 時間, $(\rho c)_{f}$ : 流体の熱容量, $\boldsymbol{V}:$ 流速ベクトル, $x$ : 熱伝導率 である。

Table 1 に解析条件を示しているが, Fig. 1，2 におい て空洞の構造寸法および地山規模は, $H_{c} / B=1.5$, $r / B=0.5, \quad H_{w} / B=1.0, H_{a} / B=4.6, \quad D / B=1.9$,
Table 1 Computed conditions, thermal and hydraulic parameters.

\begin{tabular}{|c|c|c|c|c|c|c|c|}
\hline & $\begin{array}{l}\text { Cavern } \\
\text { models }\end{array}$ & Cases & $\begin{array}{l}\text { Permea- } \\
\text { bility } \\
k_{r}(\mathrm{~m} / \mathrm{s})\end{array}$ & $\begin{array}{l}\text { Poros- } \\
\text { ity } \\
n_{r}(\%)\end{array}$ & $\left\{\begin{array}{l}\text { Thermal } \\
\text { conduc- } \\
\text { tivity } \\
x_{r}(w / m k)\end{array}\right.$ & \multicolumn{2}{|c|}{$\begin{array}{c}\text { Hydraulic conditions } \\
\text { and } \\
\text { parameters }\end{array}$} \\
\hline \multirow{4}{*}{$\begin{array}{l}\text { Underground } \\
\text { cavern for } \\
\text { fuel stock } \\
\text { piling } \\
\text { (Case-1) }\end{array}$} & \multirow{3}{*}{$\begin{array}{l}\text { Single } \\
\text { cavern }\end{array}$} & $\begin{array}{c}\text { Run- } \\
1-1\end{array}$ & $\begin{array}{l}1.0 \\
\times 10^{-6}\end{array}$ & 10 & 1.76 & \multirow{4}{*}{$\begin{array}{c}h_{c} / B \\
=1.35 \\
P_{\mathrm{c}} / \gamma_{*} B \\
=1.25 \\
\gamma_{*} \\
=9.8 \mathrm{kN} / \mathrm{m}^{3} \\
\gamma_{0} / \gamma_{*} \\
=0.9\end{array}$} & \multirow{4}{*}{$\begin{array}{l}H_{w} / B=1.0 \\
H_{a} / B=4.6 \\
H_{c} / B=1.5 \\
D / B=3.9 \\
r / B=0.5 \\
\left(\rho_{r} c_{r}\right) \\
=2.2 \mathrm{MJ} / \mathrm{m}^{3} \mathrm{~K}\end{array}$} \\
\hline & & $\begin{array}{r}\text { Run- } \\
1-2\end{array}$ & $\begin{array}{l}1.0 \\
\times 10^{-8}\end{array}$ & 5 & 2.2 & & \\
\hline & & $\begin{array}{r}\text { Run- } \\
1-3\end{array}$ & $\begin{array}{l}1.0 \\
\times 10^{-10} \\
\end{array}$ & 1 & 2.42 & & \\
\hline & $\begin{array}{l}3 \text {-series } \\
\text { caverns }\end{array}$ & $\begin{array}{r}\text { Run- } \\
1-4\end{array}$ & $\begin{array}{l}1.0 \\
\times 10^{-8}\end{array}$ & 5 & 2.2 & & \\
\hline \multirow{4}{*}{$\begin{array}{l}\text { Rock cavern } \\
\text { for reposing } \\
\text { radioactive } \\
\text { nuclides } \\
\text { (Case-2) }\end{array}$} & & \begin{tabular}{|r|} 
Run- \\
$2-1$ \\
\end{tabular} & $\begin{array}{l}1.0 \\
\times 10^{-10} \\
\end{array}$ & 5 & 2.0 & \multirow{4}{*}{$\begin{array}{c}b / B \\
=0.4 \\
h_{d} / B \\
=1.0\end{array}$} & \multirow{4}{*}{$\begin{array}{l}(\rho c)_{\mathrm{t}} \\
=4.2 \mathrm{MJ} / \mathrm{m}^{3} \mathrm{~K} \\
\left(\rho_{\mathrm{w}} \mathrm{c}_{\mathrm{w}}\right) \\
=3.0 \mathrm{MJ} / \mathrm{m}^{3 \mathrm{~K}} \\
x_{\mathrm{w}}=1.7 \mathrm{~W} / \mathrm{m} \mathrm{K} \\
k_{\mathrm{w}}=1.0 \times 10^{-4} \\
\mathrm{n}_{\mathrm{w}}=30 \% \mathrm{~m} / \mathrm{s}\end{array}$} \\
\hline & $\begin{array}{l}\text { Single } \\
\text { cavern }\end{array}$ & $\begin{array}{r}\text { Run- } \\
2-2 \\
\end{array}$ & $\begin{array}{l}1.0 \\
\times 10^{-12}\end{array}$ & 1 & $"$ & & \\
\hline & & $\begin{array}{r}\text { Run- } \\
2-3\end{array}$ & $\begin{array}{l}1.0 \\
\times 10^{-14} \\
\end{array}$ & 1 & $"$ & & \\
\hline & $\begin{array}{l}3 \text {-series } \\
\text { caverns }\end{array}$ & $\begin{array}{r}\text { Run- } \\
2-4\end{array}$ & $\begin{array}{l}1.0 \\
\times 10^{-14}\end{array}$ & 1 & $"$ & & \\
\hline
\end{tabular}

$H_{0} / B=9.0$ とし, 加温式原油備蓄における原油貯油槽 高さは $h_{c} / B=1.35$, 原油の比重 $\gamma_{0} / \gamma_{w}=0.9$, 空洞上部 の原油ガス圧 $P_{G} / \gamma_{w} B=1.25^{9)}\left(\gamma_{w}\right.$ : 水の単位体積重量, $\left.\gamma_{w}=9.8 \mathrm{kN} / \mathrm{m}^{3}\right)$ とする. 一方, 放射性廃棄物の岩盤処 分におけるキャニスター寸法は, $h_{d} / B=1.0, b / B=$ 0.4 ととる. また, 岩盤の透水・伝熱物性值は, 原油備 蓄の場合は, 深さ数十 $\mathrm{m}$ における均質良好岩盤の場合 を想定して，透水係数 $k_{r}=1.0 \times 10^{-6} \sim 1.0 \times 10^{-10} \mathrm{~m} / \mathrm{s}$, 空隙率 $n_{r}=1 \sim 10 \%$, 熱伝導率 $\boldsymbol{x}_{r}=1.76 \sim 2.42 \mathrm{~W} /$ $\mathrm{m} \cdot \mathrm{K}$, 等価熱容量 $\left(\rho_{r} c_{r}\right)=2.2 \mathrm{MJ} / \mathrm{m}^{3} \mathrm{~K}$, 流体の熱容量 $(\rho c)_{f}=4.2 \mathrm{MJ} / \mathrm{m}^{3} \mathrm{~K}$ と ${ }^{2), 5), 9)}$, 他方放射性廃棄物岩盤 処分の場合は深さ数百 $\mathrm{m}$ 以上の深層の場合を想定し, $k_{r}=1.0 \times 10^{-10} \sim 1.0 \times 10^{-14} \mathrm{~m} / \mathrm{s}, \quad n_{r}=1 \sim 5 \%, \quad \varkappa=2.0$ $\mathrm{W} / \mathrm{m} \cdot \mathrm{K}$ とする ${ }^{5), 10)}$. 一方, 沖積 - 風化帯における水理 · 伝熱定数は, $k_{w}=1.0 \times 10^{-4} \mathrm{~m} / \mathrm{s}, n_{w}=30 \%,\left(\rho_{w} c_{w}\right)=$ $3.0 \mathrm{MJ} / \mathrm{m}^{3} \mathrm{~K}, x_{w}=1.7 \mathrm{~W} / \mathrm{m} \cdot \mathrm{K}$ とする. ここで, 諸量 の添字 $r, w$ はそれぞれ岩盤, 沖積・風化帯であるこ とを意味する. 解析は, 単設, 連設空洞の両方について 行われるが, 要素数, 節点数は, 原油空洞の単設の場合

$(944,519)$ ，連設の場合 $(1540,831)$ で，核廃棄物 処分空洞の場合はおのおの $(934,514),(1510,821)$ であった。

\section{（2）変形 FLIC 法による解析法 ${ }^{11), 12) ~}$}

式( 1 )，（2 ）を同時に連立させて計算するに当たって, 式（1）は従来の Galerkin 有限要素法により行うが, 式（2）の伝熱方程式の解法には変形FLIC 法を適用 する.この種の移流伝熱・拡散方程式の解法に当たって, 普通の差分法や有限要素法を用いると流速の増大に伴っ て解が振動し, 数值計算上の不安定を生じることがよく 知られている. そこで, 本論では式 (2) の解法におい て数値的に安定でしかも計算時間の節減を行うため, 高 レイノルズ数の非粘性・非圧縮流解析に優れているとさ れている変形 FLIC 法を本解法に適用する.

変形 FLIC 法は，FLIC 差分法を有限要素法にしば 
しば用いられる三角形要素系に対して展開し得るよう 足立 $(1977)^{13)}$ により考案されたもので, FLIC 法そ のものは, Los Alamos 科学研究所グループの Rich

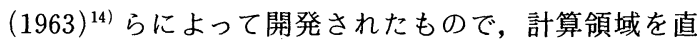
交格子によって多数の Cell に分割し, 各 Cell 内の有す る輸送量 (質量, 運動量, エネルギー等) の時間的変化 を次のように 2 段階に分けて計算するものである.つま り，はじめの第 1 段階では, Cell の移動に関する輸送 項を除いた式を各 Cell について解き，この Euler 的段 階での中間的諸量を求める. 次の第 2 段階では, Cell が前時点で求めた中間的諸量をもって空間格子を移流に よって移動するとして, 新しい時刻の流れ場の諸量を求 めるものである．この方法では，流体運動を記述する Lagrange, Euler の 2 通りの方法の特長が一体となっ て取り入れられている点が特徵といえる ${ }^{15)}$. 以下に式

（2）の定式化を具体的に述べる.

いま, 計算領域を有限要素法と同様に Fig. 3 のように 三角形に分割し，その中の任意の要素 $j$ に注目する. ここに, 図中の $i, \bar{i}: i=1,2,3$ は三角形の頂点および 対辺を意味する. また, $j, j_{i}(i=1,2,3)$ は各三角形 の重心であるよする. そこで, 式 $(2)$ を Fig. 3 の任意 の閉曲線内で面積積分すると次のようになる.

$$
\int_{s_{j}}\left[\frac{\partial T}{\partial t}+\operatorname{div}(\eta \boldsymbol{V} T)\right] d S=\int_{S_{j}}[\operatorname{div}(a \cdot \operatorname{grad} T)] d S
$$

ここに, $\eta=(\rho c)_{f} /(\rho c), a=x /(\rho c), S_{j}$ : 要素 $j$ の領域 • 面積である.

式（3）にGauss の発散定理を適用して整理すると次 のようになる.

$$
\begin{aligned}
& \int_{s_{j}} \frac{\partial T}{\partial t} d S+\int_{\Gamma_{j}} \eta V_{n} T d s=\int_{\Gamma_{j}} \varepsilon_{n} d s \\
& \left\{\begin{array}{c}
\varepsilon_{n} \\
\varepsilon_{s}
\end{array}\right\}=\left(\begin{array}{cc}
l & m \\
-m & l
\end{array}\right)\left\{\begin{array}{c}
\varepsilon_{x} \\
\varepsilon_{z}
\end{array}\right\},\left\{\begin{array}{c}
\varepsilon_{x} \\
\varepsilon_{z}
\end{array}\right\}=a \cdot \operatorname{grad} T \\
& =\left(\begin{array}{ll}
a_{x x} & a_{x z} \\
a_{z x} & a_{z z}
\end{array}\right)\left\{\begin{array}{l}
\partial T / \partial x \\
\partial T / \partial z
\end{array}\right\}
\end{aligned}
$$

ここに, $\Gamma_{j}$ : 要素 $j$ を構成する境界, $V_{n}$ : 境界上にお ける $n$ 方向の速度, $l, m$ : 外向き法線 $n$ の方向余弦で

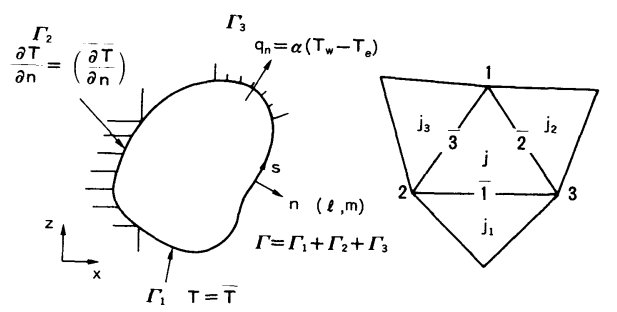

Fig. 3 Schematic presentation of flow domain and triangular finite elements of heat conduction problem.
ある.

そこで，上述したようにFLIC 法を適用して 2 段階 に分けて差分化するため,はじめに式（3）の左辺を Lagrange 的微分を用いて表わし式（4）を書き直すと 次のようになる.

$$
\frac{D}{D t} \int_{s_{j}} T d S=\int_{\Gamma_{j}} \varepsilon_{n} d s
$$

さらに, Lagrange 的微分を前進差分で近似すると,

$$
\frac{\tilde{T}_{j}-T_{j}^{(n)}}{\Delta t} S_{j}=\sum_{i=1}^{3} l_{\bar{i}} \varepsilon_{n \bar{i}}
$$

となる.ここに, $\tilde{T}_{j}$ : 要素 $j$ における中間的な值, $T_{j}^{(n)}$ : 要素 $j$ における時刻 $t=n \Delta t$ での温度, $\Delta t$ : 時間增 分, $l_{\bar{i}}$ : 辺 $\bar{i}$ の長さであり, 図の辺上の值 $\varepsilon_{n \bar{i}}$ は辺 $\bar{i}$ を 共有する 2 要素の平均值で表わす.

これより，時刻 $(n+1) \Delta t$ における中間的な温度 $\tilde{T}_{j}$ は， 式 $(7)$ から次のように算定される.

$$
\tilde{T}_{j}=T_{j}^{(n)}+\frac{\Delta t}{S_{j}} \sum_{i=1}^{3} l_{\bar{i}} \varepsilon_{n \bar{i}}
$$

次に，第 2 段階では式（4) と（6）のそれぞれの左辺 を等置することにより，

$$
\frac{D}{D t} \int_{s_{j}} T d S=\int_{s_{j}} \frac{\partial T}{\partial t} d S+\int_{\Gamma_{j}} \eta V_{n} T d s
$$

となって, 離散化すると,

$$
\frac{\tilde{T}_{j}-T_{j}^{(n)}}{\Delta t} S_{j}=\frac{T_{j}^{(n+1)}-T_{j}^{(n)}}{\Delta t} S_{j}+\sum_{i=1}^{3} l_{\bar{i}} P_{\bar{i}}
$$

となる．したがって, 時刻 $t=(n+1) \Delta t$ における要素 $j$ における温度 $T_{j}^{(n+1)}$ は次のように導かれる.

$$
T_{j}^{(n+1)}=\tilde{T}_{j}-\frac{\Delta t}{S_{j}} \sum_{i=1}^{3} l_{\bar{i}} P_{\bar{i}} \cdots
$$

ここで，P $P_{\bar{i}}$ は風上差分の考え方を導入して次のように 表わす.

$$
\begin{aligned}
& P_{\bar{i}}=\eta V_{n \bar{i}}\left[\delta_{i} \tilde{T}_{j \bar{i}}+\left(1-\delta_{i}\right) \tilde{T}_{j}\right] \\
& \delta_{i}=\delta \quad V_{n \bar{i}}<0 \quad \text { (辺 } \bar{i} \text { を通じて流入) } \\
& \delta_{i}=1-\delta \quad V_{n \bar{i}}>0 \quad \text { (辺 } \bar{i} \text { を通じて流出) }
\end{aligned}
$$

ここに, $\delta$ は上流パラメーターで, $0.5 \leq \delta \leq 1$ の值をと る.

以上が変形 FLIC 法による定式化の概要であり，境界 条件としては次のようにとる.

$$
\begin{aligned}
& T=\bar{T} \text { on } \Gamma_{1}, \partial T / \partial n=\overline{(\partial T / \partial n)} \text { on } \Gamma_{2} \\
& q_{n}=\alpha\left(T_{w}-T_{e}\right) \text { on } \Gamma_{3}
\end{aligned}
$$

ここで, 一 (バー) はその境界において既知であること を示し, $q_{n}$ : 単位面積当たりの熱流量, $\alpha$ : 熱伝達率, $T_{w}$ : 表面温度, $T_{e}$ : 外気温である.

したがって, 岩盤の伝熱現象を式（8）と式（11）を 用いて, 式 (13) の境界条件を考慮することにより時刻 $t=(n+1) \Delta t$ の温度 $T_{j}^{(n+1)}$ を求めることができる.なお, 計算の精度に関しては, 事前に理論解との比較により十 分に検証を行った ${ }^{16)}$. 


\section{3. 解析結果とその考察}

Table 1 に示した計算条件に基づいて, 二次元の浸透 流および移流伝熱解析を次の 2 つの場合，つまり 1) 加 温式貯油空洞，および2）放射性廃棄物処分空洞につい て空洞周辺の伝熱の基本的性質について吟味する.

\section{（1）空洞周辺の流れの基礎的性質}

伝熱について検討する前に空洞周辺の流れの性質を調 べておくため，おのおのの利用形態における半断面軸対 称の単設および連設空洞周辺の流速べクトルを示した Fig. 4，5に注目しよう. 同図には，流れの構造をつか むため圧力水頭 $P_{r} / \gamma_{w}$ を境界水位 $H_{0}$ で割った比も同時 に示してある.まず，Fig.4(a) は，単設加温式貯油空 洞の場合における流速ベクトルと圧力分布であって，同 図中（b）は放射性廃棄物処分空洞のそれを対比しつつ 示したものである．両者を比較して二，三の特徴を挙げ
ると，貯油空洞 (Table 1 の Case-1 に対応) の場合の 空洞流入無次元流速ベクトルは空洞上半曲面で空洞底面 におけるそれに比べてやや大きくなっており，また，無 次元圧力水頭 $P_{r} / \gamma_{w} H_{0}$ は, 空洞が空となっている廃棄 物処分空洞の場合に比べ，空洞内にガス圧および油圧の ため，空洞近傍で高くなっていることが認められる。一 方, 湧水量に注目すると, おのおのの無次元湧水量 $q_{c}^{*}$ $=q_{c} / k_{r} B$ は, 貯油空洞の場合 $q_{c}^{*}=8.2$ であり, 廃棄物 処分空洞の場合 $q_{c}^{*}=11.0$ である. つまり，この場合貯 油空洞湧水は，空洞内が空である場合に比べて $25 \%$ 程 度湧水量が小さくなることが知れる. 次に, 連設空洞に おけるそれらに目を向け，同様にFig. 5(a)，(b) に注 目する．単設の場合と同様に貯油空洞上半曲面における 流速ベクトルが底面におけるそれより大きくなってお り, かつ圧力水頭も貯油空洞近傍において廃棄物処分空 洞のそれより大きくなっていることがはっきりと知れ

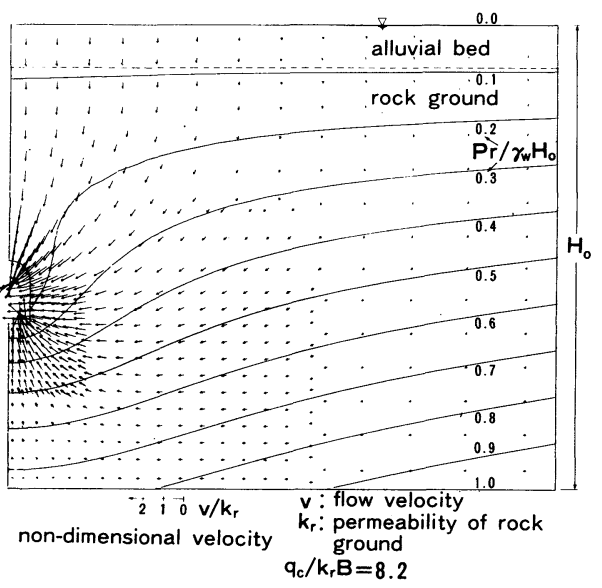

(a) Case-1

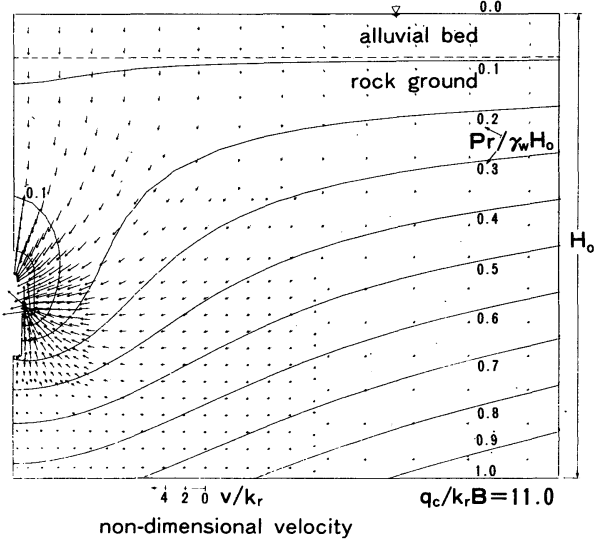

(b) Case-2

Fig. 4 Flow patterns and distributions of pressure head for single cavern.

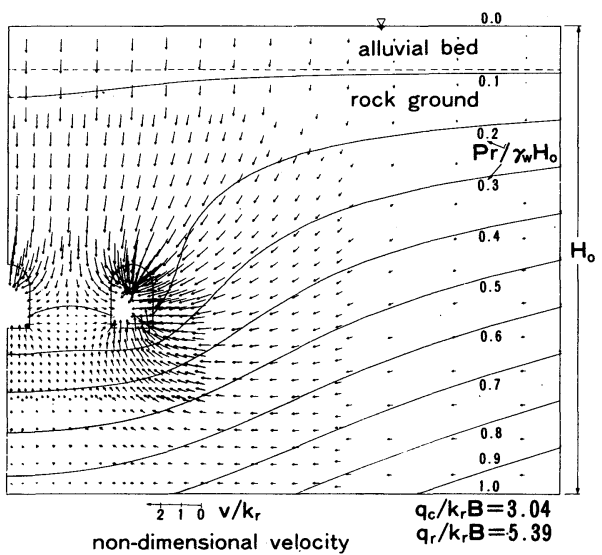

(a) Case-1

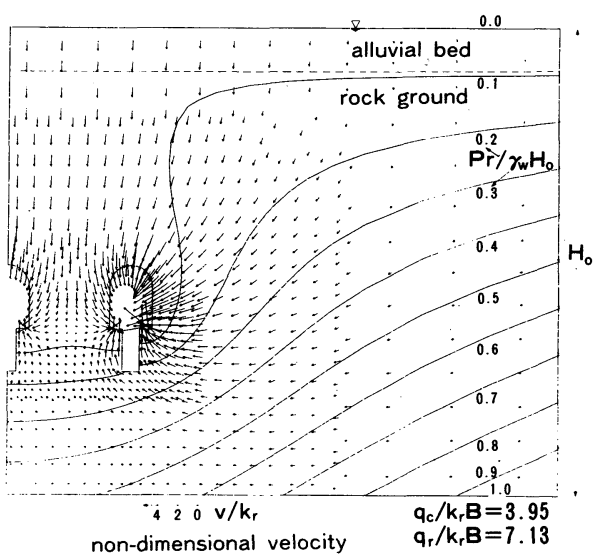

(b) Case-2

Fig. 5 Flow patterns and distributions of pressure head for 3 -series caverns. 
る.さらに，空洞間の流速ベクトルは，いずれの場合に おいても右側空洞外側のそれに比べて小さくなってい る.ここで明らかにされた流れの性質は水理条件や水理 量が多少変わっても一般的に認められることが別のこの 種の解析加らも認められている。

\section{（2）空洞周辺伝熱の基礎的性質}

すでに明らかとなったごとき地下水流れをもつ岩盤地 山に加温油およびキャニスタ一熱源がある場合につい て，それによる伝熱帯の広がりや温度分布について検討 することとするが，空洞伝熱における熱輸送の方向は空 洞への地下水流の方向と逆になる．つまり，熱はその熱 源から外向きに広がるが，一方地下水は空洞に向かって 収束流れとなるために，おのおのは輸送方向が逆となり， 伝熱はこの地下水流の影響を受けることになる。この点 は，始めに注意しておきたい大切なところである．

Fig. 6 は, 加温式貯油空洞の場合における空洞周辺の無 次元温度分布 $\theta$ (ここに, $\theta=\left(T-T_{i}\right) /\left(T_{0}-T_{i}\right), T$ : 温度, $T_{i}$ : 初期地山温度, $T_{0}$ : 熱源温度とする) を経過時刻 0.6 年，および 2.0 年後について示したものである.こ こで経過時刻は, Fig.7 (後述) を含めたこれらすべて の図において左右半断面における実時間を統一的に比較 検討しやすくするため, 空洞幅を $B=5.0 \mathrm{~m}$ と一定にし て求めたものである. また，図中の $\tau$ は無次元時間 $\tau$ $=\tilde{u} t / B\left(\tilde{u}\right.$ : 空洞湧水量 $q$ を壁面面積之空隙率 $n_{r}$ で 割った值で壁面に垂直な浸透移流速度の平均値， $t$ : 実 時間， $B$ : 空洞幅）であり, 経過時刻におけるその值を 併せて示しておいた。図中（a）は Table1に揭げたよ うに岩盤地山の透水係数 $k_{r}=1.0 \times 10^{-6} \mathrm{~m} / \mathrm{s}$, 空隙率 $n_{r}$ $=10 \%$, 熱伝導率 $x_{r}=1.76 \mathrm{~W} / \mathrm{m} \cdot \mathrm{K} ，(\mathrm{~b})$ は $k_{r}=1.0$ $\times 10^{-8} \mathrm{~m} / \mathrm{s}, \quad n_{r}=5 \%, x_{r}=2.2 \mathrm{~W} / \mathrm{m} \cdot \mathrm{K}$, (c) は $k_{r}=$ $1.0 \times 10^{-10} \mathrm{~m} / \mathrm{s}, n_{r}=1 \%, x_{r}=2.42 \mathrm{~W} / \mathrm{m} \cdot \mathrm{K}$ と与えた 場合における等温度分布をおのおの示しているが，おの おのの伝熱を支配する無次元量は, ペクレ数 $P e$ を $P e$ $=\tilde{u} d / a_{r}$ (ここに, $d:$ 空隙率に等しい空隙体積を $\mathrm{m}$ 単位で表わし, その体積と等価な円管直径, $a_{r}$ : 熱拡 散係数， $a_{r}=\boldsymbol{x}_{r} /\left(\rho_{r} c_{r}\right)$ とする) と定義して表わす ${ }^{5)}$. そ うすれば, Fig. 6 中 (a) の場合は $P e=8.01 \times 10^{-2}$, (b) $P e=9.04 \times 10^{-4}$, (c) $P e=1.84 \times 10^{-5}$ ということにな る. 現象的にみれば, ペクレ数が小さいほど伝熱におい て伝導が卓越するようになってくるが，具体的な伝熱帯 の広がりや温度分布がざうなるかについては計算結果か ら考えてみよう。

まず, Fig. 6(a) はP $P e=8.01 \times 10^{-2}$ の場合における $\theta$ 分布であり, 伝熱帯の広がりはかなり小さく,わずか に空洞側面および底面の一部にみられる程度である．空 洞上半曲面および空洞底面両端部において特に伝熱帯の 広がりがみられないのは, Fig.4(a) の流速ベクトル分

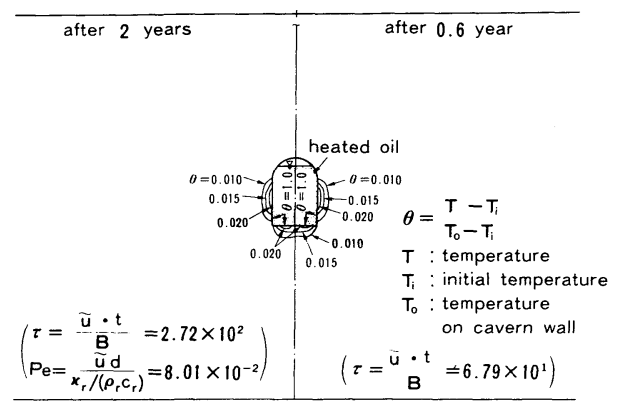

(a) $\theta$ after 0.6 and 2.0 years for Run-1-1

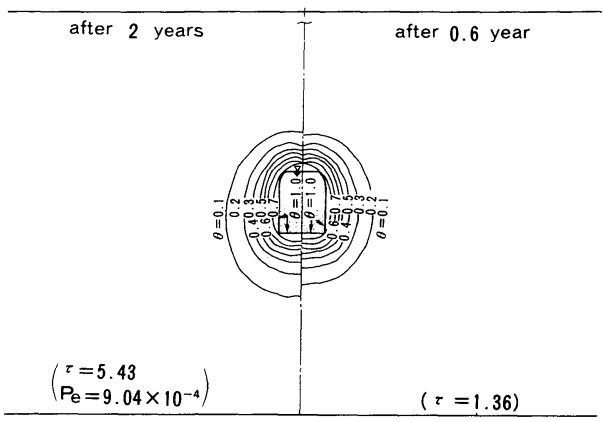

(b) $\theta$ after 0.6 and 2.0 years for Run-1-2

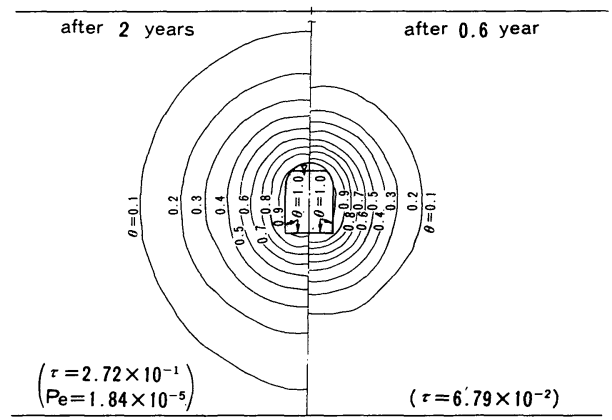

(c) $\theta$ after 0.6 and 2.0 years for Run-1-3

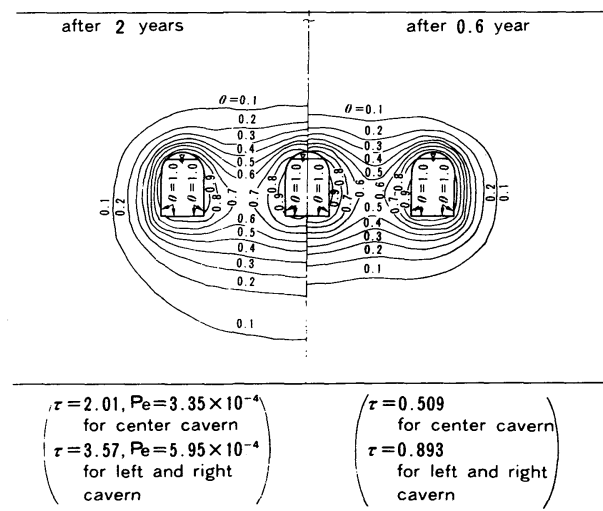

(d) $\theta$ after 0.6 and 2.0 years for Run-1-4

Fig. 6 Distributions of non-dimensional temperature $\boldsymbol{\theta}$ after 0.6 and 2.0 years in the case of Case-1. 
布からわかるように，この部分における流速が底面中央 や側面に比べて大きいことによるものであって，地下水 流れの影響を受けていることを如実に示している．経過 時刻 0.6 年における温度分布と 2.0 年におけるそれに変 化はなく, 0.6 年後にはすでに定常状態になっているも のと判読できる．結局，このように透水性の大きい地山 の場合は移流伝熱が伝熱場を支配するため伝熱帯の広が りはあまり拡大しない. (b) 図は, $P e=9.04 \times 10^{-4}$ の 場合，(c) は $P e=1.84 \times 10^{-5}$ の場合のそれらであるが, いずれの場合も（a）のそれに比べて伝熱帯は大きく広 がっている. 特に (c) の場合は空洞熱源を中心に同心 円的な広がりを示しつつ伝熱帯が一層の広がりをみせ, $P e$ 数が小さいため伝導支配となっていることがわか る. また，(b) の場合における空洞上部と下部の 0.6 年および 2.0 年における $\theta$ 分布に着目すると, 上部よ り下部でその広がりが大きくなっていることが認められ る.この場合も空洞上半曲面と底面流速の違いによる影 響が現われている．同じく（b）の場合は伝導と移流伝 熱による影響が同時に現われ，地下水流の性質によって 伝熱帯の広がりと形態に微妙な変化を与えていることは 大変興味深いところであろう.

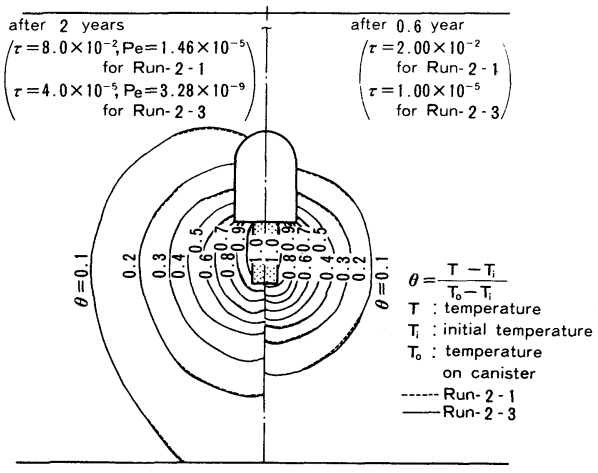

(a) $\theta$ after 0.6 and 2.0 years for single cavern

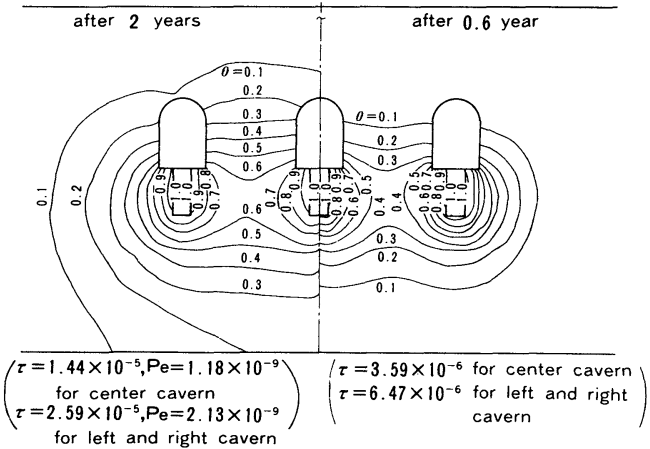

(b) $\theta$ after 0.6 and 2.0 years for 3 -series caverns

Fig. 7 Distributions of non-dimensional temperature $\theta$ after 0.6 and 2.0 years in the case of Case-2.
Fig. 6(d) は, 同図の（b) と同じ水理条件下におけ る連設空洞の場合の $\theta$ 分布を示したものであるが，伝 熱帯の広がりは空洞相互間および空洞下部で大きく，左 右空洞外側および空洞上部で小さくなっている．全体的 にみると $\theta$ 分布は, 単設のそれよりやや大きくなって いる．これは，空洞周辺流速ベクトルが連設の場合に単 設のそれに比へでや小さくなり，Pe 数も単設では $P e=9.04 \times 10^{-4}$ となっていることに起因し，伝導の影 響が一層強くなっていることによる。

他方，放射性廃棄物処分空洞における空洞周辺の無次 元温度分布に注目するため, Fig. 7 に目を転じよう. Fig.7(a) は単設空洞におけるそれをRun-2-1（ $k_{r}=$ $\left.1.0 \times 10^{-10} \mathrm{~m} / \mathrm{s}, n_{r}=5 \%\right)$ の場合は破線で, Run-2-3 $\left(k_{r}\right.$ $\left.=10 \times 10^{-14} \mathrm{~m} / \mathrm{s}, n_{r}=1 \%\right)$ のそれは実線で同時に示し たものであって, $P e$ 数はおのおの $P e=1.46 \times 10^{-5}$, $3.28 \times 10^{-9}$ となる。 これより， $\theta$ 分布はキャニスターを 中心に同心円状に広がり，Run-2-1 と Run-2-3におけ るそれにほとんど差が認められないことがわかる。この ことは，ある程度流速が小さくなる（Pe 数が小さくな ることに対応）と伝熱場は完全に伝導支配となって, 空 洞へ向かう地下水流れによる影響はほとんど無視できる ことを示唆しているものといえよう（b）は，連設空 洞における $\theta$ 分布を示したものである. $P e$ 数は $10^{-9}$ のオーダーと小さく，この場合もやはり伝導のみによっ て伝熱帯が広がり，地下水流による影響は現われていな いことを明解に確認できる。

以上，実際にも即した規模と条件を導入し，かつ実験 で得られている伝熱・水理パラメーターを用いて, 加温 式貯油空洞および放射性廃棄物処分空洞における空洞周 辺伝熱について解析的検討を行ったが，深さ数十 $\mathrm{m}$ 程 度の均質岩盤を対象として建設される加温式貯油空洞の 場合は，岩盤の伝導のみならず地下水流れによる移流伝 熱の影響を受けることが新たに明らかにされた。他方， 深さ数百 $\mathrm{m}$ 以上の深層岩盤を対象とした放射性廃棄物 処分空洞の場合の伝熱は，ほとんど伝導によって支配さ れることが判明した。

\section{4. 伝熱実験}

ここで，3. で提案した変形 FLIC 法によって解析し た結果を具体的に可視化すると同時に実験的に再現する ための模型実験と空洞周辺伝熱の三次元構造を解明する ためのサンドモデル中の伝熱実験の二通りの実験を述べ る.

\section{（1）空洞下キャニスター周辺の伝熱の可視化}

\section{a ）実験装置と実験方法}

伝熱における自然対流の発生有無に加え伝熱形状・分 布の拡散速度を知り，かつ計算手法の妥当性を確認する 


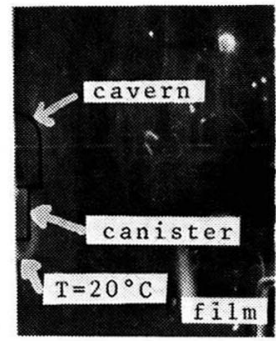

(a) Atter early tew minutes

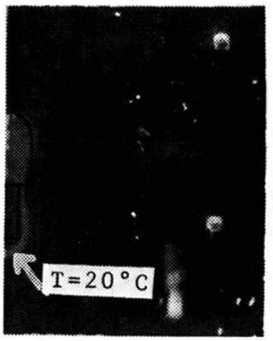

(b) After 2.0 hours

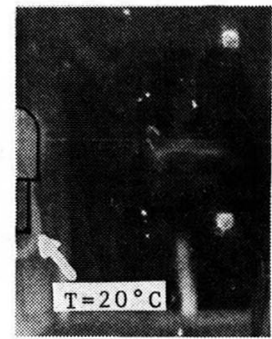

(c) After 3.0 hours

Photo 1 Temperature distributions around canisters for Exp-1.

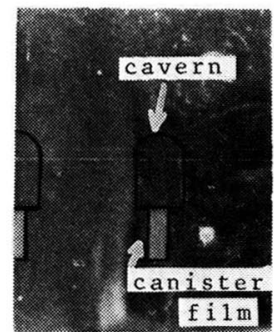

(a) Atter early tew minutes

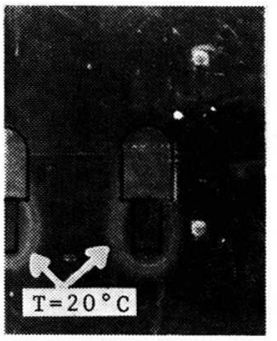

(b) After 1.0 hours

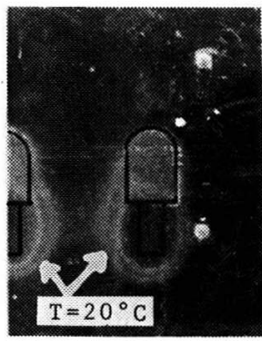

(c) Mrter $2 . u$ nours

Photo 2 Temperature distributions around canisters for Exp-2.

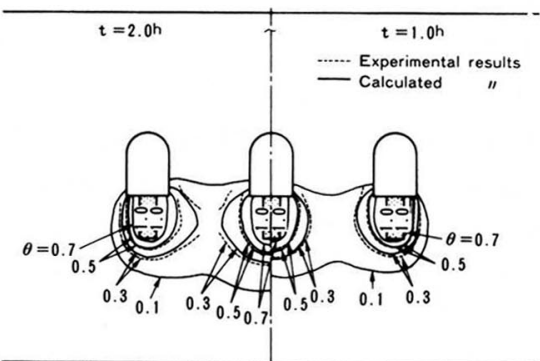

Fig. 9 Comparison with experimental distributions of non-dimensional temperature $\theta$ and calculated ones after 1.0 and 2.0 hours for Exp-2.

定常状態となっていることが判断される.このような地 山条件においては, 自然対流の発生は認められない.

Photo 2 は, 連設空洞におけるものを示しているが，こ の場合は単設のそれに比べ, 特に空洞間で伝熱帯の形成 が早く, 2 時間後には相互の空洞伝熱帯が重複・合併し ている.これら実験ケースの単設および連設空洞周辺の $P e$ 数を計算してみると, 単設の場合は $P e=\tilde{u} d_{r} /$ $\left(x_{r} /\left(\rho_{r} c_{r}\right)\right)=1.60 \times 10^{-2}$ となり, 連設の場合の中央空洞 $P e=5.88 \times 10^{-2}$, 右側空洞 $P e=10.4 \times 10^{-2}$ となって いる. 3. で述べたように $P e$ 数が大きいと移流伝熱が 卓越してくることになるから, 単設空洞で伝熱帯が小さ くなっていることは, 上述の解析結果と整合しており, 十分納得できよう.

同様に, Fig. 9 は感温液晶フィルムの色彩を読み取る ことによって得られた実験温度分布と同じ条件の解析解

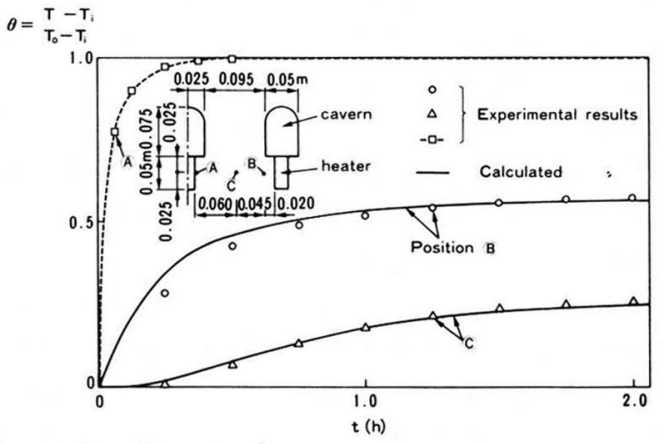

Fig. 10 Non-dimensional temperature $\theta$ with time for Exp-2.

によるそれを同時に示したものである．実験による温度 分布は視覚的なもので量的精度には限界があり, あまり 高い量的評価は期待できず，多くの等温度線を描くこと はできないが空洞間の伝熱速度が大きいことははっきり わかる. また, Fig. 10 は, 地山モデル中の温度センサー により計られた節点温度経時変化をキャニスター近傍の

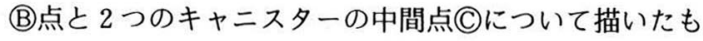
のである. いずれの測点も初期の温度上昇は大きいが, 2 時間後ではかなり定常状態に近くなっていることが判 読できる.ここで示した実験結果と解析結果はよく一致 している.

結局, 感温液晶フィルムによる伝熱実験を通じて, Fig. 6，7 に与えた解析結果は十分妥当なものであるこ とを知ることができ，かつこのような実験に当たって感 温液晶フィルムの有用性が実証されたものといえよう. 


\section{（2）空洞周辺の三次元伝熱特性}

実際の岩盤地下空洞の長さは有限であり, 三次元構造 をもつことになる. すでに, 二次元伝熱については可視 化実験によって知ることができたので, ここで, 空洞下 部キャニスター周辺の伝熱形態と三次元構造を大型サン ドモデル実験と二次元および三次元解析に基づいて検討 することにする ${ }^{18)}$. Fig. 11 は実験装置の全体を示し, 水槽の平面寸法は $l=2.1 \mathrm{~m}$ の正方形で深さ $0.6 \mathrm{~m}$ であ る. 帯水層周辺に境界水位 $H_{0}=0.52 \mathrm{~m}$ を与え, 空洞乇 デルは幅 $B=0.05 \mathrm{~m}$, 奥行長さ $L=0.15,0.30,0.45$ $\mathrm{m} の 3$ 種とし, 熱源となるキャニスター (幅 $b=0.01 \mathrm{~m}$, 高さ $h_{d}=0.1 \mathrm{~m}$, 奥行長さ $L=0.15,0.30,0.45 \mathrm{~m}$ の 3 種）がある場合である. また，水面形は 13 本の多孔 管を埋設して水位を観測することにより測る．実験は， 図中右側に示したグラウト施工した 3 種の空洞下部に定 温キャニスターモデルをもつ空洞を埋設し，その周辺に 26 点の温度測定用熱電対を埋め込んで, 所定の土被り 下で涌水量と周辺温度経時変化と分布を測定しようとい うものである. 地山モデルとなる砂は $50 \%$ 粒径 $d_{50}=$ $0.38 \mathrm{~mm}$, 均等係数 1.12 のきれいな砂であり, 透水係 数 $k_{r}=1.02 \times 10^{-3} \mathrm{~m} / \mathrm{s}$, 空隙率 $n_{r}=43 \%$ であった. 実 験手順は, はじめに熱電対を所定の位置に埋め込み, 砂 を一様に充てんしつつ空洞モデルを設定し，所定の周辺 境界水位を与えて, 水位低下分布, 涌水量および温度分 布を測定するものである. 空洞モデルのグラウト帯は, 地下水流れを制御する目的で設けたもので, 多孔空洞フ レームに透水性の小さい綿布を覆って作成した．グラウ 卜帯の厚さは $1 \mathrm{~mm}$ で, その透水係数は $k_{f}=3.59 \times 10^{-8}$ $\mathrm{m} / \mathrm{s}$ であった.

Fig. 12 は, $L / B=9(L / 2 l=0.214)$ の場合の等無次 元温度分布 $\theta$ を空洞有 - 無の両者について, 二次元と 三次元熱伝導解析および二次元移流伝熱解析の結果を実 験自由水面も含め同時に示したものである.この場合の 伝熱パラメーターは, $x_{r} /\left(\rho_{r} c_{r}\right)=2.0 \times 10^{-3} \mathrm{~m}^{2} / \mathrm{h}$, $(\rho c)_{f} /\left(\rho_{r} c_{r}\right)=1.4$, 空洞壁面での熱伝達率 $\alpha=0.5$ $\mathrm{W} / \mathrm{m}^{2} \mathrm{~K}$ であった。 まず, 最も単純に空洞がないとすれ ば，地下水流動がないので式（2）において $\boldsymbol{V}=0$ とみ なせ, 伝熱は伝導のみによって起こる。この場合に $\theta$ 分布の広がりは, $y=0$ の $x-z$ 平面, つまり熱源長手中 央平面で最も大きく, $y>0$ に向かうにつれてやや小さ くなっている. また, 三次元と二次元の解析結果はほと んど一致しており, 特に三次元効果はみられない. 他方, グラウト施工空洞がある場合には, 空洞へ向かう浸透流 が発生し， $\theta$ 分布は空洞のない場合のそれに比べて全体 に小さくなり, 特に空洞上で顕著となっている. 次に,

Fig. 12 の $y=0$ の $x$ 平面内にある空洞近傍の代表的 な測点 $\mathrm{A}$ の無次元温度 $\theta$ の経時変化を示したものが

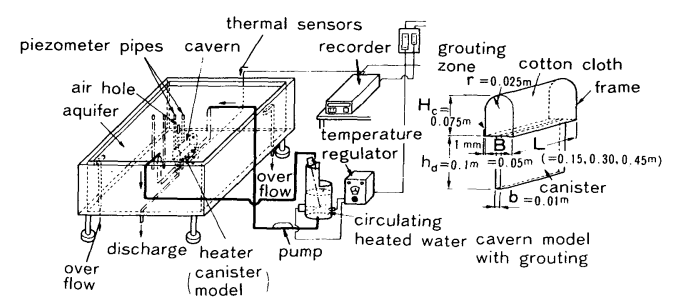

Fig. 11 Experimental apparatus of heat conduction around the canister.

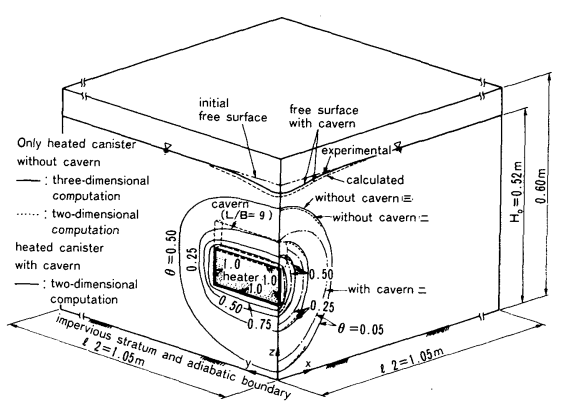

Fig. 12 Three-dimensional distributions of non-dimensional temperature $\theta \quad\left(=\left(T-T_{i}\right) /\left(T_{0}-T_{i}\right)\right)$ around the canister for $L / B=9$.

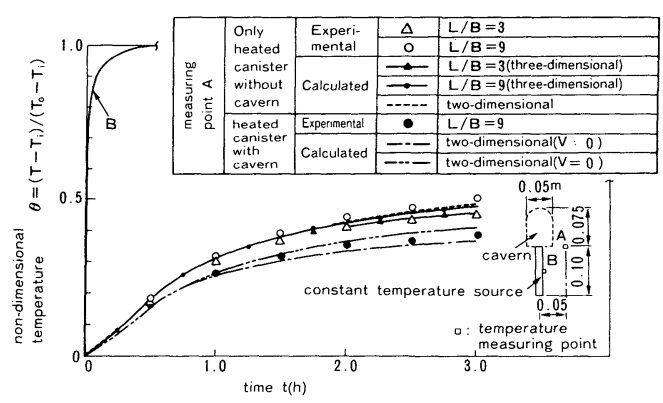

Fig. 13 Non-dimensional temperature $\theta$ with time at measured point $A$.

Fig. 13であるが，図中にはこうした結果に加えて $L / B$ $=3$ の場合の解析結果も同時に示し, さらに解析と同様 の条件で行った実験結果も併せて示した．空洞のないと した場合の $L / B=3$ と 9 における $\theta$ の経時変化に注目 すると, 実験・解析ともに $L / B=3$ の場合の方がやや 小さくなっているものの有義な差は認めにくい. また, 空洞のあるときの $\theta$ は, 実験・解析値ともに空洞のな い場合のそれに比べて小さくなっており, 空洞掘削によ る地下水変化および移流伝熱の影響がはっきりと実験的 にも知れる. この場合の $P e$ 数は $P e=1.0 \times 10^{-2}$ とな る.こういった実験はここで述べたもののほかに多数 行ったが,こうした代表的な結果から判断しても, 空洞 寸法の数倍程度の範囲では, 空洞周辺伝熱による三次元 効果は小さく, 二次元解析 ·予測によってもある程度推 
定し得ることが判明した。

\section{5. 結 論}

燃料地下備蓄および核廃棄物の岩盤処分にかかわる技 術的課題の中でも昨今特に脚光を浴びている燃料貯蔵空 洞およびキャニスター周辺の伝熱現象に注目して, 新し く数值解析手法を開発し,解析と実験によって伝熱特性, 分布，その経時変化，および空洞への浸透による影響も 含めて研究を試みた。地下水流れと伝熱解析には変形 FLIC 法を導入し，より実際的な解析を通じて空洞にか かわる未知の伝熱現象をいくつか究明し得た。一方，実 験には感温液晶フィルムを供えた細粒ガラス球帯水層モ デルによる可視化，およびサンドモデルによる伝熱の三 次元構造の解明を通して, この種の研究に有効な新しい 実験手法を応用・開発した。本研究で得られた成果は以 下のように要約される.

（1）加温式貯油空洞周辺の流速分布が貯油時と空の 状態では特に空洞下部で異なり，地下水流の影響を強く 受け, 今回与えた水理条件下では, 貯油時の涌水量（貯 油率 $95 \%$ 時，ガス圧 $P_{G} / \gamma_{w} B=1.25$ の場合）は空の場 合より $25 \%$ ほよ゙小さくなる.

（2）移流伝熱方程式の解法に変形 FLIC 法を適用 し,ペクレ数の広い範囲にわたって安定でかつ精度のよ い解を得ることができた。

（3）深さ数十 $m$ 程度の岩盤を対象とした加温式貯油 空洞周辺伝熱については，地下水流れによる移流伝熱の 影響を受け，空洞周辺の流速ベクトル分布の差異が伝熱 帯に顕著に現われる.

（4）深さ数百 $\mathrm{m}$ 以上の岩盤を対象とした放射性廃棄 物処分空洞下のキャニスター熱源周辺では，地山の伝導 が支配的となる。

（5） ペクレ数 $P e$ がほぼ $10^{-5}$ 程度以上の場合は地 下水流による移流伝熱を考慮する必要があるが，10-5 以下の場合は伝導支配となるため，それを考慮する必要 はないという結果を得た。

（6）加温式貯油連設空洞周辺における伝熱帯の広が りは，流速の小さくなる空洞間および空洞下部で大きく なる。

（7）感温液晶フィルムによる帯水層中の伝熱実験へ の応用が可能であることが実証された.

（8）岩盤均質地山の深い熱源による伝熱の三次元性 は空洞寸法の数倍程度の範囲では小さく, 二次元解析・ 予測によっても十分推定できることがわかった。

ここで述べた空洞を対象とした伝熱の研究は，従来ほ とんぞ扱われていなかったもので，今回の研究成果を通 じて今後の現象解明に 1 つの足掛かりを得ることができ たように感じている.

\section{参 考 文 献}

1）塩尻弘雄ほか：周辺温度分布之熱応力, 電力土木, No 166, pp. 49 61，1980-5.

2) 桜井俊男：石油地下備蓄菊間実証プラントについて, 土 質工学会「土と基礎」, 29-1 (276), No.1210, pp. 15 22, 1981.

3）土井和己：わが国における放射性廃棄物隔離の地球科学 上の問題, 日本原子力学会誌, Vol. 22, No. 8, pp. 33 40, 1980.

4）下岡 浩：高レベル放射性廃棄物の地層処分場近傍にお ける温度上昇之熱応力の数値解析法, 日本原子力学会誌, Vol. 24, No. 11, pp. 57 63, 1982.

5）佐藤邦明・佐々木康夫：岩の伝熱および熱水浸透流によ る熱拡散係数の実験的研究，土木学会論文集，第 351 号 /II -2, pp. 127 135, 1984-11.

6) Johansen, $\phi$. and Frivik, P.E. : Thermal properties of soil and rock materials, The 2nd Int. Sym. Ground Freezing, June pp. 427 453, 1980.

7) Heuze, F.E. : High-temperature mechanical physical and thermal properties of granic rocks-a review, Int. J. Rock Mech. Min. Sci. \& Geomech. Abstr., Vol.20, No. 1, pp. 3 10, 1983.

8) Combarnous, M. and Bories, S. : Hydro-thermal convection in saturated porous media, Advances in Hydroscience, edited by Ven te Chow, Vol.10, Academic Press, pp. 231 307, 1975.

9）駒田広也ほか：水封式燃料地下貯蔵用空洞周辺岩盤の浸 透流に関する検討，土木学会論文報告集，第 300 号， pp. $69 \sim 80,1980-8$

10) Gale, J.E. et al. : Hydrogeologic characteristics of a fractured granite, AWRC Conf. Groundwater in fractured Rock, Canberra, pp. 95 108, 1982.

11）驚津久一郎・田中義一・池川昌弘：変形FLIC 法による 非圧縮粘性流解析, 日本航空宇宙学会誌, 第 27 巻, 第 307 号, pp. 26 34, 1979-8.

12）伊藤 洋・佐藤邦明・清水昭男 : 変形 FLIC 法による亀 裂性岩盤内の熱・物質拡散解析, 土木学会第 29 回水理講 演会論文集, pp. 893～898，1985-2.

13）足立武司・过村玄隆・今泉全通：分岐集合部を有する管 内非定常流の一解析法, 日本機械学会論文集 (第 2 部), 43巻 366 号, pp. 596 602, 1977-2.

14) Rich, A. : Method for Eulerian Fluid Dynamics, LASL Report LAMS-2826, 1963.

15）廣瀬直喜：流体力学における計算機実験の方法とその応 用, 日本航空宇宙学会誌, 第 20 巻, 第 277 号, pp. 25 -38, 1972-12.

16）清水昭男ほか：放射性廃棄物の陸地処分に伴う地下水污 染の評価法，熊谷技報第 37 号, 1985-7.

17）佐藤邦明：飽和多孔体および温水浸透流における温度伝 導率の実験的決定, 土木学会論文報告集, 第 320 号, pp. $57 \sim 65,1982-4$.

18）伊藤 洋 - 佐藤邦明 - 清水昭男 : 地下空洞周辺の地下水 流および伝熱の三次元特性に関する研究, 土木学会第 17 回岩盤力学に関するシンポジウム, 1985-2.

(1985.3.4 • 受付) 